Corrigendum

\title{
Corrigendum to "Biomarker MicroRNAs for Diagnosis of Oral Squamous Cell Carcinoma Identified Based on Gene Expression Data and MicroRNA-mRNA Network Analysis"
}

\author{
Hui Zhang, ${ }^{1}$ Tangxin Li, ${ }^{2}$ Linqing Zheng, ${ }^{1}$ and Xiangya Huang ${ }^{1}$ \\ ${ }^{1}$ Guanghua School of Stomatology, Hospital of Stomatology, Sun Yat-sen University, \\ Guangdong Province Key Laboratory of Stomatology, Guangdong, China \\ ${ }^{2}$ Oral and Maxillofacial Center, Kiang Wu Hospital, Macau \\ Correspondence should be addressed to Xiangya Huang; hxiangya@mail.sysu.edu.cn \\ Received 20 November 2017; Accepted 5 December 2017; Published 28 December 2017 \\ Copyright (C) 2017 Hui Zhang et al. This is an open access article distributed under the Creative Commons Attribution License, \\ which permits unrestricted use, distribution, and reproduction in any medium, provided the original work is properly cited.
}

In the article titled "Biomarker MicroRNAs for Diagnosis of Oral Squamous Cell Carcinoma Identified Based on Gene Expression Data and MicroRNA-mRNA Network Analysis" [1], there was a mistake in the first affiliation. The corrected affiliations are shown above.

\section{References}

[1] H. Zhang, T. Li, L. Zheng, and X. Huang, "Biomarker micrornas for diagnosis of oral squamous cell carcinoma identified based on gene expression data and microrna-mrna network analysis," Computational and Mathematical Methods in Medicine, vol. 2017, Article ID 9803018, 8 pages, 2017. 


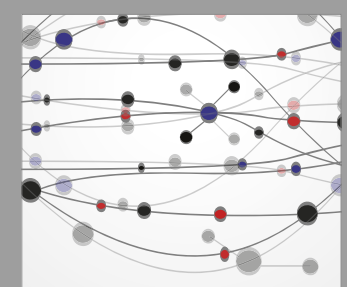

The Scientific World Journal
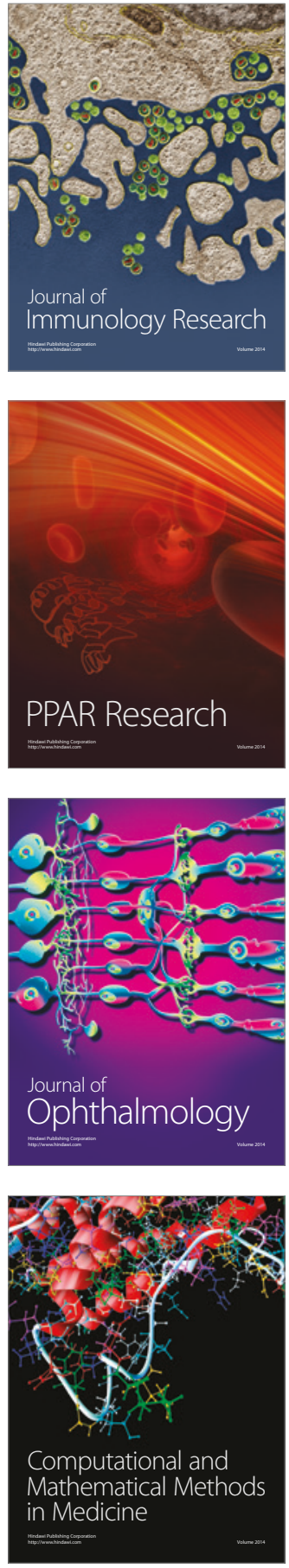

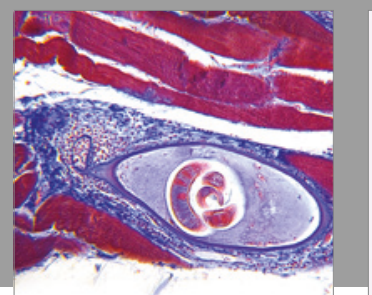

Gastroenterology Research and Practice
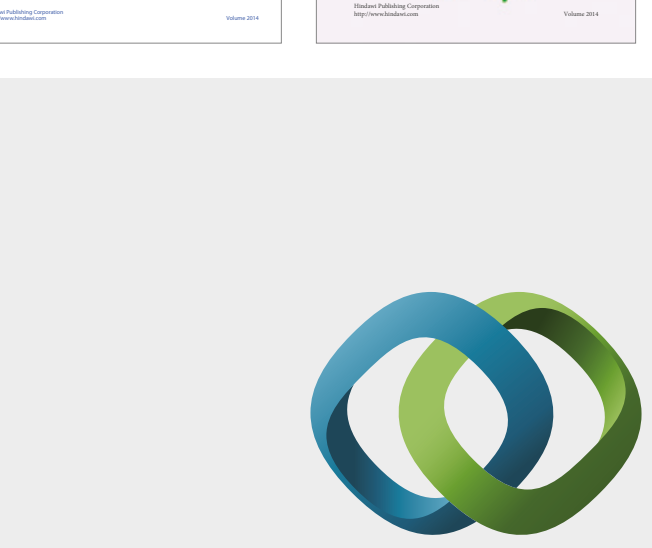

\section{Hindawi}

Submit your manuscripts at

https://www.hindawi.com
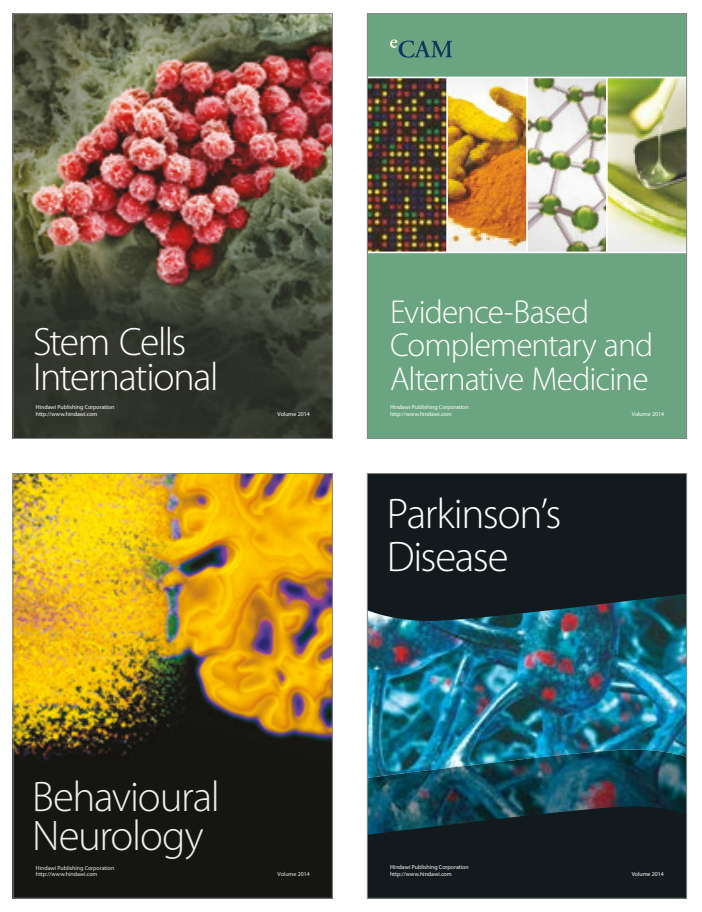
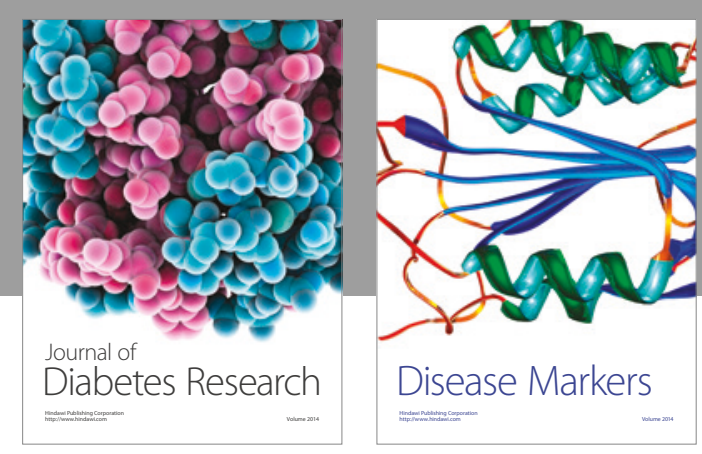

Disease Markers
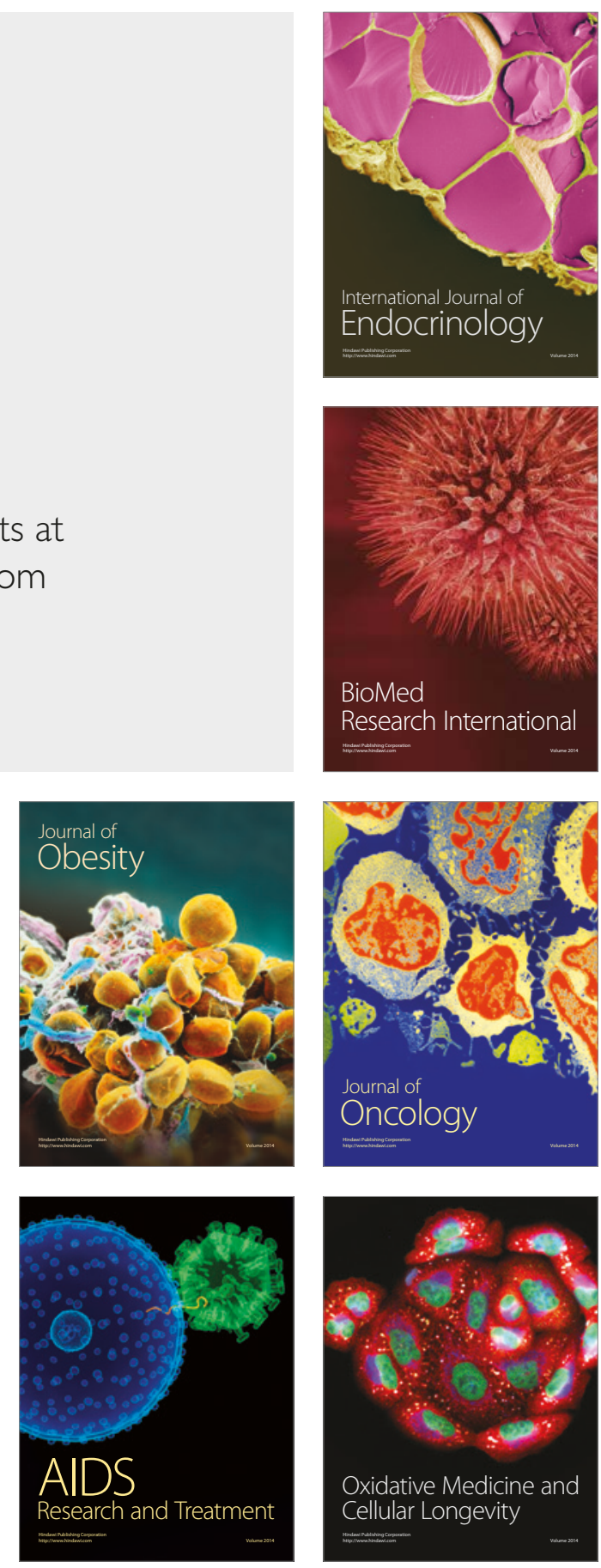